\title{
Deskripsi Kesalahan Siswa dan Scaffoldingnya Dalam Menyederhanakan Pecahan Bentuk Aljabar
}

\author{
Indah Puspitasari Maharani ${ }^{1}$, Sisworo ${ }^{1}$, Hendro Permadi ${ }^{1}$ \\ ${ }^{1}$ Pendidikan Matematika-Universitas Negeri Malang
}

\section{INFO ARTIKEL}

\section{Riwayat Artikel:}

Diterima: 26-06-2019

Disetujui: 15-12-2019

\section{Kata kunci:}

description of student error; procedural and conceptual error; fractional algebraic form; scaffolding

deskripsi kesalahan siswa;

kesalahan prosedural dan konseptual;

pecahan bentuk aljabar; scaffolding

\begin{abstract}
ABSTRAK
Abstract: The research objectives are (1) describing the mistakes made by students in simplifying fractions of algebraic forms and (2) describing the scaffolding given to overcome student errors. The subjects in this study were UM Lab High School students in the XI IPS class who made mistakes in completing the test. The research subjects studied were 2 students categorized in the low ability category. This type of research is descriptive qualitative. Data obtained through tests and interviews. The results showed that (1) the mistakes made by students in simplifying the algebraic fractions consisted of errors in denominator equations, errors in algebraic operations, errors in algebraic factoring and errors in simplified algebraic fractions and (2) scaffolding given based on errors in point one is explaining, reviewing and restructuring and developing conceptual thinking.
\end{abstract}

\begin{abstract}
Abstrak: Tujuan penelitian adalah (1) mendeskripsikan kesalahan yang dilakukan oleh siswa dalam menyederhanakan pecahan bentuk aljabar dan (2) mendeskripsikan scaffolding yang diberikan untuk mengatasi kesalahan siswa. Subjek dalam penelitian ini adalah siswa SMA Lab UM kelas XI IPS yang melakukan kesalahan dalam menyelesaikan tes. Subjek penelitian yang diteliti sebanyak 2 siswa yang dikategorikan dalam kategori kemampuan rendah. Jenis penelitian ini adalah kualitatif deskriptif. Data yang diperoleh melalui tes dan wawancara. Hasil penelitian menunjukan bahwa (1) kesalahan yang dilakukan siswa dalam menyederhanakan pecahan bentuk aljabar terdiri dari kesalahan pada penyamaan penyebut, kesalahan pada operasi aljabar, kesalahan pada pemfaktoran aljabar dan kesalahan pada penyederhanaan pecahan aljabar dan (2) scaffolding yang diberikan berdasarkan kesalahan pada poin satu adalah explaining, reviewing dan restructuring serta developing conceptual thinking.
\end{abstract}

\author{
Alamat Korespondensi: \\ Indah Puspitasari Maharani \\ Pendidikan Matematika \\ Universitas Negeri Malang \\ Jalan Semarang 5 Malang \\ E-mail: indah.puspitasari.1703118@students.um.ac.id
}

Banyak para ahli yang telah melakukan penelitian tentang kesalahan siswa dalam belajar matematika dan mendefinisikan kesalahan (Brodie, 2014; Sarwadi \& Shahrill, 2014; Tariq, 2008). Walaupun masih banyak perdebatan yang membedakan kesalahan dan miskonsepsi, namun keduanya merupakan hasil dari aturan yang dipercayai oleh siswa. Kesalahan (error) dapat terjadi secara acak dalam kesalahan perhitungan atau hilangnya tanda akurasi pada saat menjawab suatu pertanyaan matematika sehingga menyebabkan terjadinya kesalahan dalam memperoleh jawaban yang tepat. Kesalahan (error) ini dapat terlihat dalam naskah hasil pekerjaan siswa dan dapat diatasi dengan latihan atau remedi yang berulang, sedangkan miskonsepsi merupakan kesalahan pemahaman siswa yang terjadi dari konstruksi struktur konseptual siswa dan biasa disebut kesalahan yang sistematis. Miskonsepsi memerlukan konstruksi pemahaman yang dibangun secara teratur karena telah menjadi bagian yang tak terpisahkan dari pemahaman siswa. Oleh karena itu, penelitian terhadap kesalahan matematika siswa sebenarnya merupakan upaya dalam mengatasi kesalahan pemahaman yang terjadi pada siswa dalam belajar matematika maupun sebagai upaya untuk mengurangi derajat kesalahan yang dilakukan siswa dalam mengerjakan matematika (Bentley \& Bossé, 2018; Ryan \& McCrae, 2005).

Pembelajaran matematika di kelas sering menggunakan pengetahuan prosedural maupun konseptual. Walaupun hal itu tergantung pada materi dan peran guru di kelas, namun keduanya sering digunakan dalam pembelajaran matematika di kelas. Pada umumnya pengetahuan konseptual melibatkan pemahaman tentang makna dari suatu konsep. Pengetahuan ini diperlukan untuk memahami masalah dan menghasilkan strategi baru atau menyesuaikan strategi yang dikenal untuk memecahkan masalah (Egodawatte \& Stoilescu, 2015). Dalam pengetahuan konseptual menggunakan istilah relasi pemahaman (relational understanding) yang berhubungan dengan bagaimana mengerjakan dan mengapa dalam memecahkan masalah. Pengetahuan prosedural merupakan pengetahuan tentang aturan untuk memecahkan masalah yang menuntut siswa untuk mengetahui 
bagaimana, tetapi tidak mengetahui mengapa. Pengetahuan prosedural diistilahkan sebagai alat pemahaman (instrumental understanding) untuk menggambarkan pengetahuan tentang representasi simbolik dalam matematika dan aturan atau logaritma yang digunakan dalam mengerjakan soal matematika. Suatu organisasi penasihat matematika nasional atau NMAP (The National Mathematics Advisory Panel) pada tahun 2008 menyimpulkan bahwa pemahaman konsep pecahan dan kelancaran dalam menggunakan prosedur ketika memecahkan masalah pecahan adalah tujuan dari perkembangan matematika anak (Selden \& Selden, 2009; Siegler, Thompson, \& Schneider, 2011). NMAP juga menjelaskan bahwa kompetensi pecahan memiliki kaitan erat untuk pembelajaran aljabar, keduanya terhubung dengan pembelajaran aritmatika dan konsep aljabar (Hidayanto, 2013).

Aljabar merupakan salah satu ilmu matematika dasar yang banyak mempelajari penggunaan manipulasi simbol-simbol dan huruf (Maharani \& Subanji, 2018). Belajar aljabar merupakan genelarisasi dari aritmatika sehingga cara berpikir aljabar berbeda dengan berpikir aritmatika. Berpikir aritmatika memerlukan penalaran langsung, sedangkan berpikir aljabar memerlukan penalaran dengan sesuatu simbol yang tidak diketahui (Walle, 2009). Namun, pada kenyataanya masih banyak siswa SMA yang belum lancar dalam penggunaan manipulasi simbol-simbol dalam aljabar terutama pada pecahan bentuk aljabar padahal penguasaan terhadap pecahan bentuk aljabar ini sangat penting dalam mempelajari bilangan riil dan bilangan kompleks dengan kata lain kompetensi pada pecahan bentuk aljabar dapat memberikan manfaat pada kemampuan matematika. Selain itu penguasaan terhadap pecahan bentuk aljabar sangat diperlukan untuk mengembangkan penalaran aljabar siswa misal untuk studi lanjut (Ito, 2017). Ketidaklancaran penggunaan simbol-simbol dalam aljabar ini dapat diidentifikasi dari kesalahan yang dilakukan oleh siswa baik secara konseptual maupun prosedural.

Berdasarkan hasil kajian pada silabus 2017 sekolah menengah pertama maupun sekolah menengah atas bahwa konsep pecahan bentuk aljabar telah diperkenalkan pada SMP kelas VIII dan penggunaan konsep tersebut sampai ke jenjang SMA kelas XI terutama pada materi limit fungsi, turunan, integral dan lain-lain. Dari hasil studi awal yang dilakukan oleh peneliti kepada siswa SMA Lab UM kelas XI diperoleh informasi bahwa terdapat kesalahan yang dilakukan oleh siswa dalam menyederhanakan pecahan bentuk aljabar baik dalam urutan operasi, penyamaan penyebut, operasi aljabar dan pemfaktoran aljabar. Misalnya kesalahan dalam penyamaan penyebut $\frac{3 x}{4}+\frac{2 x}{3}=\frac{17 x}{12}$ maupun kesalahan dalam pembagian aljabar, seperti $\left(\frac{1}{m n}\right):\left(\frac{n}{m}\right)=\left(\frac{1}{m n}\right) \times\left(\frac{n}{m}\right)$. Kesalahan-kesalahan perlu dideteksi oleh guru dan diberi perlakuan tertentu agar kedepannya tidak menyebabkan kesulitan bagi siswa dalam mempelajari materi limit fungsi, turunan dan integral yang didalamnya terdapat bentuk pecahan aljabar.

Bentuk perlakuan yang diberikan agar dapat mengatasi kesalahan yang dilakukan oleh siswa adalah pemberian scaffolding kepada siswa. Scaffolding yang diberikan dalam pembelajaran berupa bimbingan yang diberikan oleh seorang guru kepada siswa dalam proses pembelajaran dengan persoalan-persoalan terfokus dan interaksi yang bersifat positif dan membangun (Davis, 2015). Lebih lanjut menurut (Davis, 2015) ciri utama dari scaffolding adalah interaksi, penentuan tugas yang tepat, diagnosis tingkat kemampuan siswa dengan pencocokan level dukungan yang diberikan, menyediakan berbagai jenis dukungan dan perlahan mengurangi dukungan. Bentuk dukungan belajar dari orang dewasa atau ahli sangat penting dalam membantu siswa agar dapat meningkatkan kemampuan untuk menguasai tindakan. Ketika siswa dapat mengendalikan kemampuannya maka dia dapat menggunakannya sebagai alat (Pol, 2010). Dilihat dari bentuk dukungannya scaffolding terdiri dari tiga level menurut (Anghileri, 2006) (1) level 1 environmental provisions, level ini merupakan level dasar dalam scaffolding. Pada level ini, guru membantu siswa dengan menciptakan lingkungan belajar di dalam kelas yang digunakan dalam mendukung pembelajaran; (2) pada level 2 guru dapat membantu siswa mencapai pemahamannya dengan menjelaskan (explaining), meninjau kembali (reviewing) dan restrukturisasi (restructuring); (3) developing conceptual thinking scaffolding digunakan untuk mengembangkan pemahaman konsep atau membangun keterkaitan antar konsep.

Berdasarkan penjelasan diatas, scaffolding pada materi pecahan bentuk aljabar merupakan pemberian bantuan kepada siswa agar dapat memahami dan lancar dalam menggunakan prosedur dalam menyederhanakan pecahan bentuk aljabar. Oleh karena itu, maka penelitian ini berfokus pada deskripsi kesalahan yang dilakukan oleh siswa dalam menyederhanakan pecahan bentuk aljabar dan deskripsi scaffolding yang diberikan kepada siswa yang mengalami kesulitan dalam mengerjakan soal pecahan bentuk aljabar yang diberikan.

\section{METODE}

Metode peneltian yang digunakan adalah metode peneltian kualitatif. Penelitian kualitatif berangkat dari pengamatan kongkrit pada empirical social reality sehingga terbangun theorical frame work/paradigm. Pendekatan penelitian kualitatif memiliki kriteria yaitu (1) latar alamiah sebagai sumber data, (2) peneliti sebagai alat (instrumen), (3) mementingkan proses daripada hasil, (4) sifat penelitian analitik deskriptif, (5) analisis data secara induktif, (6) mengutamakan makna, (7) adanya batasan dan fokus penelitian, (8) desain yang bersifat sementara artinya desain penelitian kualitatif disesuaikan dengan kenyataan di lapangan sehingga tidak menggunakan desain yang telah disusun secara ketat dan kaku sehingga tidak dapat diubah lagi, (9) hasil penelitian dirundingkan dan disepakati bersama (Creswell, 2012).

Jenis penelitian ini adalah penelitian deskriptif yang bertujuan untuk menggambarkan kesalahan siswa dalam menyederhanakan pecahan bentuk aljabar dan mendiskripsikan scaffolding yang akan digunakan untuk mengatasi kesalahan tersebut. Data yang ingin diperoleh merupakan data hasil tes yang menunjukkan adanya kesalahan pada hasil pekerjaan siswa dan pernyataan siswa secara lisan terhadap apa yang dipikirkan siswa. Setelah data diperoleh kemudian dilakukan scaffolding 
sebagai upaya bantuan kepada siswa. Data ini bersifat deskriptif dengan maksud memahami fenomena tentang apa yang dialami oleh subjek penelitian berupa perilaku, persepsi serta tindakan secara holistik dan dengan cara deskripsi dalam bentuk kata-kata dan bahasa pada suatu konteks alamiah dengan memanfaatkan pendekatan alamiah (Moleong, 2014).

Penelitian dilaksanakan di SMA Lab UM pada Kelas XI IPS. Subjek penelitian adalah siswa dengan kategori rendah, setelah diberikan soal tes. Penentuan subjek juga dipertimbangkan dari masukan yang diberikan oleh guru selama mengajar matematikadi kelas XI IPS yang dapat menilai prestasi siswa dan kelancaran dalam berkomunikasi dengan peneliti dalam mengungkapkan gagasannya. Peneliti memfokuskan penelitian pada kelas XI IPS 1 karena siswa telah mendapatkan materi limit fungsi. Instrumen yang digunakan dalam peneltian ini adalah instrumen utama (peneliti), instrumen pendukung berupa lembar instrumen tes dan pedoman scaffolding. Adapun pengumpulan data melalui tes dan wawancara kepada subjek penelitian. Data yang diperoleh berupa hasil tes dan hasil wawancara berupa kalimat maupun kata-kata yang mendeskripsikan dua unsur utama tujuan penelitian ini.

\section{HASIL}

Berdasarkan hasil tes yang diberikan kepada siswa dalam menyelesaikan soal penyederhanaan pecahan bentuk aljabar dapat diketahui kemampuan siswa dalam menyelesaikan pecahan bentuk aljabar. Dari 28 siswa ditemukan bahwa delapan orang siswa dikategorikan tinggi karena telah mencapai kriteria penyelesaian soal berdasarkan indikator pecahan bentuk aljabar. Selanjutnya, terdapat 10 orang siswa yang dikategorikan dalam kategori kemampuan sedang. Siswa dalam kategori ini dalam menyelesaikan soal tes dengan prosedur maupun konsep yang setengah dari indikator yang tidak digunakan oleh siswa dalam menyelesaikan soal. Kemudian yang terakhir adalah kategori siswa dengan kemampuan rendah berjumlah 10 orang. Siswa dalam kategori ini tidak menggunakan prosedur yang memadai dalam menyelesaikan soal tes. Masing-masing kategori dipilih subjek yang menjadi perwakilan dari kategori tersebut untuk diteliti. Peneliti menyajikan dalam bentuk tabel 1 agar dapat memudahkan dalam memetakan kesalahan yang dilakukan oleh subjek. Untuk lebih jelasnya berikut kesalahan yang dilakukan oleh subjek I, II, dan III dalam menyederhanakan pecahan bentuk aljabar dari soal tes.

Tabel 1. Indikator Kesalahan Subjek Penelitian Sebelum M1 dan Sesudah M2 Scaffolding

\begin{tabular}{llcccc}
\hline \multirow{2}{*}{ No. } & \multirow{2}{*}{ Indikator Kesalahan } & \multicolumn{2}{c}{ S-I } & \multicolumn{2}{c}{ S-II } \\
\cline { 3 - 6 } & & MI & M2 & M1 & M2 \\
\hline 1. & Penyamaan penyebut PBA & $\sqrt{ }$ & $\sqrt{ }$ & \\
2. & Pembagian PBA & $\sqrt{ }$ & $\sqrt{ }$ & \\
3. & Perkalian PBA & $\sqrt{ }$ & $\sqrt{ }$ & \\
4. & Penjumlahan PBA & $\sqrt{ }$ & $\sqrt{ }$ & \\
5. & Pengurangan PBA & $\sqrt{ }$ & $\sqrt{ }$ & \\
6. & Pemfaktoran aljabar & $\sqrt{ }$ & $\sqrt{ }$ & \\
7. & Penyederhanaan PBA & $\sqrt{ }$ & $\sqrt{ }$ & $\sqrt{ }$ \\
\hline
\end{tabular}

\section{Keterangan: $\quad$ Kode Sebelum scaffolding : M1}

Hasil Pekerjaan Subjek (S-I) Dalam Menyederhanakan Pecahan Bentuk Aljabar

Secara keseluruhan, kesalahan yang dilakukan S-I dalam menyederhanakan pecahan bentuk aljabar cukup banyak. Hal ini tampak dari kesalahan langkah-langkah penyederhanaan yang terjadi secara berurutan. Berikut ini rekap kesalahan berdasarkan hasil pekerjaan S-I dalam menyederhanakan pecahan bentuk aljabar pada tes adalah sebagai berikut.

\section{a. Penyamaan Penyebut}

Berdasarkan hasil pekerjaan S-I tampak kesalahan yang dilakukan S-I dalam langkah menyamakan penyebut yaitu dengan menuliskan $\left(\frac{1}{x+y}-\frac{-2}{x+y}\right):\left(\frac{3}{x-y}-\frac{-4}{x+y}\right)$. Gambar 1 merupakan hasil pekerjaan S-I pada soal tes.

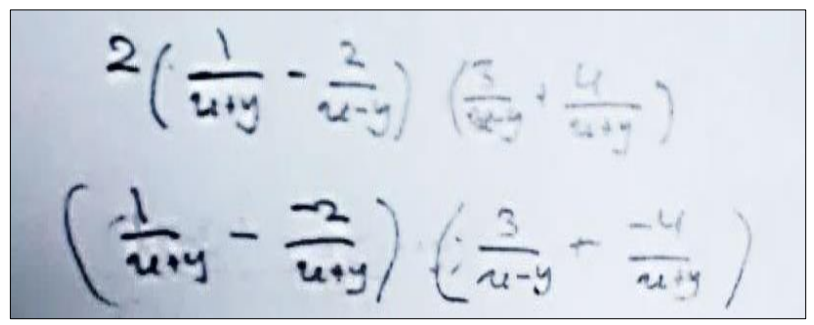

Gambar 1. Hasil Pekerjaan S-I terhadap Penyamaan Penyebut 
Dari apa yang ditulis S-I kesalahan penyamaan penyebut sangat mendasar bagi S-I, tanpa mengetahui atau lupa bagaimana konsep menyamakan penyebut, S-I langsung menuliskan $\frac{1}{x+y}-\frac{-2}{x+y}$ pada bagian lain yaitu $\frac{3}{x-y}-\frac{-4}{x+y}$ sehingga perlu diberi perlakuan dalam mengatasi kesalahan dalam menyamakan penyebut. Pada bagian penyamaan penyebut soal tes yang dikerjakan oleh S-I, kesalahan yang tampak adalah kesalahan baik secara prosedural maupun konseptual. Scaffolding yang diberikan pada langkah ini adalah sebagai berikut.

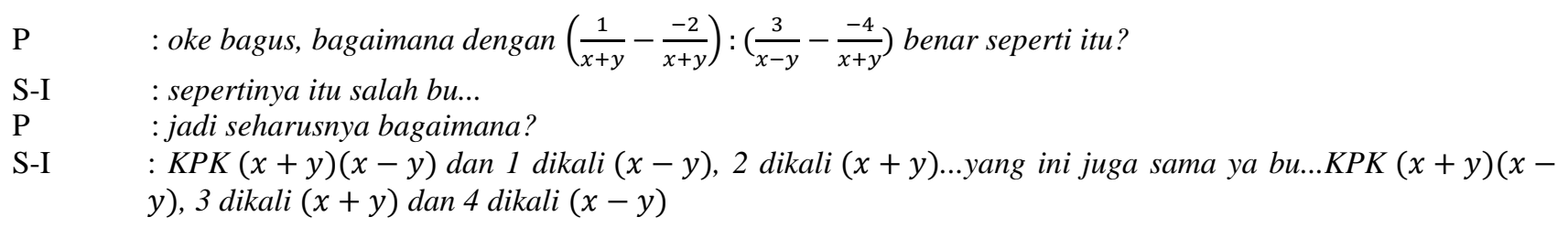

Dari hasil wawancara dan pemberian scaffolding kepada S-I dapat diketahui bahwa kesalahan yang dilakukan pada penyamaan penyebut disebabkan karena tidak memahami konsep pecahan dengan baik sehingga keseluruhan pekerjaan S-I juga salah secara prosedural. Karena kesalahan ini, maka peneliti mencoba memberikan scaffolding dengan cara memberikan contoh pada pecahan biasa dengan maksud agar siswa dapat membangun kembali pemahamannya tentang pecahan dan memberi kesempatan bagi S-I mengerjakan konsep pecahan aljabar.

b. Perkalian Aljabar

Pada langkah perkalian bentuk aljabar, kesalahan tampak pada perkalian $(2 x+2 y)(2 x+2 y)$ dan menghasilkan $-x+y$ setelah dioperasikan. Hasil tersebut tanpa memperhatikan urutan operasi kemudian ditulis sebagai hasil akhir $\frac{-x+y}{2 x^{2}+4 y-2 y}$. Hasil pekerjaan S-I disajikan pada gambar 2.

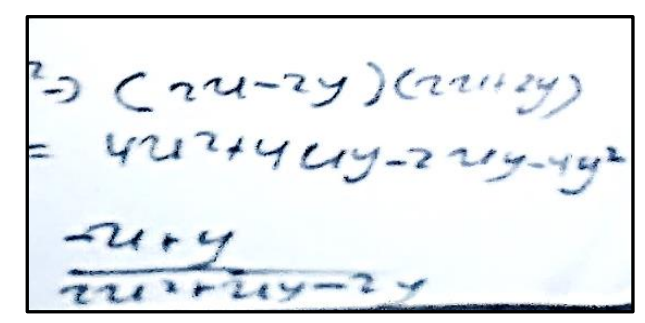

\section{Gambar 2. Hasil Pekerjaan S-I terhadap Perkalian}

Pada kesalahan perkalian ini juga ditandai dengan kesalahan yang dilakukan S-I dalam menuliskan bentuk perkalian $(2 x+2 y)(2 x+2 y)$. Namun tidak diketahui dari mana asalnya. Peneliti kemudian menanyakan bentuk aljabar tersebut kepada S-I agar memperoleh kejelasan terhadap hasil pekerjaannya.

$\mathrm{P} \quad$ : ini hasil pekerjaanmu pada perkalian, apakah benar hasil yang kamu peroleh pada perkalian $(2 x+$ $2 y)(2 x+2 y)$ benarkah seperti itu?

S-I : tidak bu, saya mengerjakan $(2 x+2 y)(2 x+2 y)$ dari penyebutnya bu...

$\mathrm{P} \quad$ : lalu kamu kenapa bisa menuliskan seperti ini?

S-I : : saya hanya menuliskan apa yang saya tahu bu... seperti itu penyebutnya dikalikan

P : nah kamu kan sudah mendapatkan hasil dari penyamaan penyebut, sekarang bagaimana kamu mengalikan bentuk aljabar itu? (sambil menunjuk ke hasil pekerjaan S-III)

S-I $\quad$ : seperti itu bu... mengalikan pembilang 1 dengan $x-y$ dan -2 dengan $x+y$

Dari hasil scaffolding diatas, pada langkah perkalian ini diberikan kepada S-I pada saat S-I tidak memahami pekerjaannya dengan baik. S-I hanya menuliskan bentuk yang tidak konsisten dari hasil perkalian aljabar $(2 x+2 y)(2 x+2 y)$ yang berasal dari penyebut. Dia memahami penyebutnya harus dikalikan, namun bukan dalam bentuk pecahan. Oleh karena itu peneliti berupaya memberikan scaffolding pada langkah perkalian ini dengan memberikan bantuan berupa scaffolding terhadap penyamaan penyebut dahulu kemudian disusul konsep pada penyamaan penyebut dan memberikan kesempatan kepada S-I utnuk mengerjakan langkah pada perkalian ini. S-I kemudian menuliskan hasil perkalian tersebut dan memudahkannya dalam memahami bentuk perkalian setelah penyamaan penyebut. Bentuk scaffolding disini berupa reviewing, explaining, dan restructuring dengan maksud siswa dapat mengungkapkan pemahamannya, menjelasakan dan merestrukturisasi pemahaman siswa kembali. 
b. Penjumlahan Dan Pengurangan Bentuk Aljabar

Pada langkah ini masih berkaitan dengan kesalahan yang dilakukan S-I pada langkah sebelumnya yaitu penyamaan penyebut, pembagian, perkalian dan urutan operasi. Pada gambar 2, hasil pekerjaan S-I terhadap perkalian tampak bahwa kesalahan perkalian juga berlajut ke penjumlahan dan pengurangan bentuk aljabar sehingga hasil yang diperoleh salah.

Kesalahan yang dilakukan S-I dalam penjumlahan dan pengurangan aljabar seperti yang telah disebutkan diatas dikarenakan kesalahan dalam menyamakan penyebut dan berlanjut sampai mendapatkan jawaban akhir yang salah. Oleh karena itu peneliti berusaha memberikan scaffolding kepada S-I.

$\mathrm{P} \quad$ : hasil yang kamu peroleh pada soal 2 ini adalah $\left(\frac{-1}{2 x+2 y}\right):\left(\frac{-1}{2 x-2 y}\right)$ benarkah seperti itu?

S-I : tadinya saya kira mengerjakan dengan melihat bagian pembilang yang dikurangkan $\left(\frac{1}{x+y}-\frac{-2}{x+y}\right):\left(\frac{3}{x+y}-\right.$ $\left.\frac{-4}{x+y}\right)$, sebelumnya saya tidak mengerti soalnya...

$\mathrm{P} \quad$ : nah, setelah kamu mencari penyamaan penyebut tadi coba tuliskan hasil operasi pecahan aljabarnya...

S-I $\quad$ : ya seperti yang tadi bu... harus disamakan dulu penyebutnya bu, yaitu $(x+y)(x-y)$

$\mathrm{P} \quad$ :setelah itu apa yang kamu kerjakan lagi?

S-I : mengoperasikanya...

Dari hasil pekerjaan S-I pada perkalian aljabar pada pembilang, diperoleh informasi bahwa kesalahan yang terjadi pada perkalian disebabkan karena pertama, langkah pada penyamaan penyebut yang salah sehingga menghasilkan perkalian yang salah dan kedua karena ketidakteraturan dalam mengerjakan perkalian baik secara konsep maupun prosedural dari hasil pekerjaan subjek sebelumnya. Adapun scaffolding yang diberikan pada perkalian aljabar ini adalah scaffolding dalam bentuk reviewing dan restructuring kepada S-I dengan maksud agar siswa dapat mengerjakan langkah perkalian ini dengan meninjau kembali hasil pekerjaannya dan merestrukturisasi pemahaman terhadap perkalian bentuk aljabar pada soal tes.

\section{c. Pembagian Bentuk Aljabar}

Kesalahan pembagian bentuk aljabar S-I ditandai dengan menuliskan hasil dari langkah menyamakan penyebut. Berdasarkan hasil pekerjaan S-I, hasil penyamaan penyebut adalah $-2 x+2 y: 2$. Berikut Gambar 1.3 hasil pekerjaan S-I dalam pembagian bentuk aljabar.

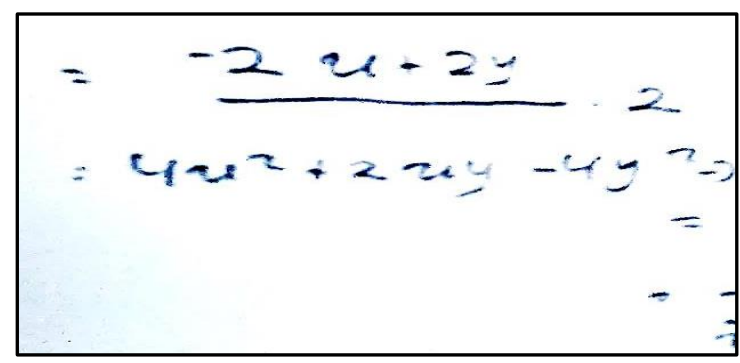

\section{Gambar 3. Hasil Pekerjaan S-I terhadap Pembagian}

Dari keterangan diatas, kesalahan yang terjadi pada pembagian ini tampak merupakan kesalahan yang tidak beraturan dan konsisten. Kesalahan disini ditandai dari hasil pembagian aljabar yang tidak dipahami oleh S-I sehingga menuliskan $-2 x+$ 2y:2. Kesalahan ini disadari oleh S-I namun tidak dapat menuliskan dengan benar hasil pembagian. Adanya ketidakkonsistenan ini membuat peneliti memberikan scaffolding terhadap pembagian aljabar.

$\mathrm{P} \quad$ : apakah benar hasil yang kamu peroleh pada pembagian $-2 x+2 y: 2$ benarkah seperti itu?

S-I : tidak bu saya tidak tahu...waktu itu saya mengerjakan 1 dijumlahkan dengan 1 yaitu 2 ini bu...

dan $-2 x+2 y$

$\mathrm{P} \quad$ : darimana asalnya bentuk itu?

S-I : : pembilang dan penyebut bu yang saya dapatkan...

$\mathrm{P} \quad$ : apakah langkah mu itu sudah benar? Kalau tidak benar seharusnya bagaimana?

S-I $\quad$ : salah bu....dari hasil penyamaan penyebut beda dengan itu...

$\mathrm{P} \quad$ : nah setelah kamu mendapatkan hasil perkalian bagaimana dengan operasi pembagian?

S-I : balik dan kalikan bu... 
Kesalahan dalam pembagian pada soal tes dari ketidakkonsistenan S-I dalam menuliskan bentuk aljabar yang diperolehnya. Peneliti kemudian memberikan scaffolding kepada S-I pada pembagian aljabar dengan explaining, reviewing hasil pekerjaan S-I pada soal sebelumnya yang telah dipelajari oleh S-I pembagian dapat ditulis sebagai bentuk balik dan kalikan.

d. Pemfaktoran Aljabar

Pemfaktoran pada langkah yang dikerjakan oleh S-I tidak tampak menggunakan langkah pemfaktoran. Siswa hanya menuliskan hasil akhir yang diperolehnya yaitu $\frac{-x+y}{2 x^{2}+4 y-2 y}$. Pada bagian pemfaktoran ini setelah S-I menemukan dan menuliskan hasil pekerjaannya, setelah menyelesaikan langkah pembagian aljabar. Disini tampak bahwa S-I menuliskan dalam bentuk dibawah ini setelah pemberian scaffolding. Berikut hasil pekerjaan S-I terhadap pemfaktoran pada Gambar 1.4 berikut.

$$
\begin{aligned}
& -(-x-3 y)(u-y)(u+y) \\
= & \frac{-u-3 y}{7 u-1 y}
\end{aligned}
$$

\section{Gambar 4. Hasil Pekerjaan S-I terhadap Pemfaktoran}

f. Penyederhanaan Pecahan Aljabar

Langkah penyederhanaan juga tidak nampak dari hasil pekerjaan S-I. Sebagai bagian kesalahan yang terakumulatif mulai dari urutan operasi sampai ke kesalahan dalam penyederhanaan bentuk aljabar. Hasil pekerjaan S-I juga dalam penyederhanaan dikerjakan S-I dalam bentuk tidak teratur sehingga mendapatkan hasil akhir yaitu $\frac{-x+y}{2 x^{2}+4 y-2 y}$. sehingga pada bagian ini peneliti berupaya memberikan bantuan kepada S-I dengan menanyakan kepada S-I tentang hasil pekerjaannya.

$\mathrm{P} \quad$ : kamu telah pelajari penyederhanaan pada soal 1 tadi, nah sampai tahap ini, coba kamu perhatikan bentuk aljabar yang telah apakah itu sudah dalam bentuk yang paling sederhana?

S-I : : sepertinya belum kan bu...

$\mathrm{P} \quad$ : mana yang menurutmu harus disederhanakan? kalau belum apa yang kamu lakukan?

S-I $\quad$ : menghilangkan bentuk ini bu....dengan mencoret yang sama bu...

$\mathrm{P} \quad$ : selain variabel sama dikarenakan apa?

S-I : ee...faktor bu...

$\mathrm{P} \quad$ : iya faktor yang sama atau FPB ingat ya...

Scaffolding yang diberikan kepada S-I berdasarkan kesalahan yang dilakukan oleh S-I pada penyederhanaan pecahan aljabar ini dengan memberikan kesempatan bagi S-I merestrukturisasi hasil pekerjaanya dan pada soal 1 telah diberikan contoh pecahan biasa yang dapat disederhanakan. Kesalahan yang dilakukan S-I dimulai dari kesalahan dalam urutan operasi hingga hasil akhir dari penyederhanaan pecahan aljabar yang tidak tepat. Jadi scaffolding yang diberikan dimulai dari langkah awal penyamaan penyebut.

\section{Hasil Pekerjaan Subjek (S-II) Dalam Menyederhanakan Pecahan Bentuk Aljabar}

Kesalahan subjek S-II pada tes soal tes dalam menyederhanakan pecahan bentuk aljabar sebagai berikut.

a. Penyamaan penyebut

Hasil pekerjaan S-II dalam menyederhanakan pecahan bentuk aljabar dengan menuliskan penyamaan penyebut seperti pada gambar 5 .

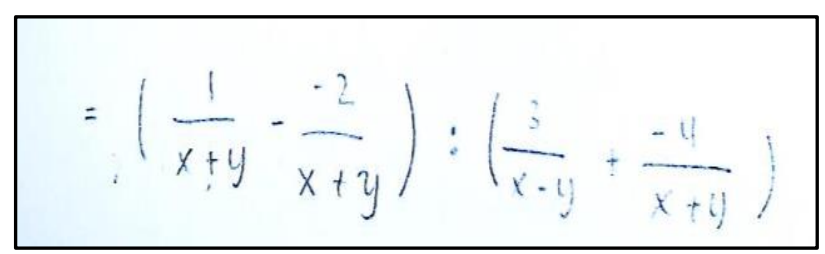

Gambar 5. Hasil Pekerjaan S-II terhadap Penyamaan Penyebut 
Berdasarkan hasil pekerjaan S-II, tampak bahwa kesalahan dalam menyamakan penyebut masih belum dimengerti oleh S-VI terutama dalam menyamakan penyebut pecahan bentuk aljabar. Alih-alih menyamakan penyebut, S-II fokus pada pembilang yang ditulis lagi dengan tanda negatif pada masing-masing tanda operasi pecahan. Upaya perbaikan dari penyamaan penyebut kepada S-II dengan menggali pemahaman S-II tentang pekerjaannya ini dan membantu memberikan bantuan scaffolding kepada S-II. Adapun scaffolding yang diberikan adalah sebagai berikut.

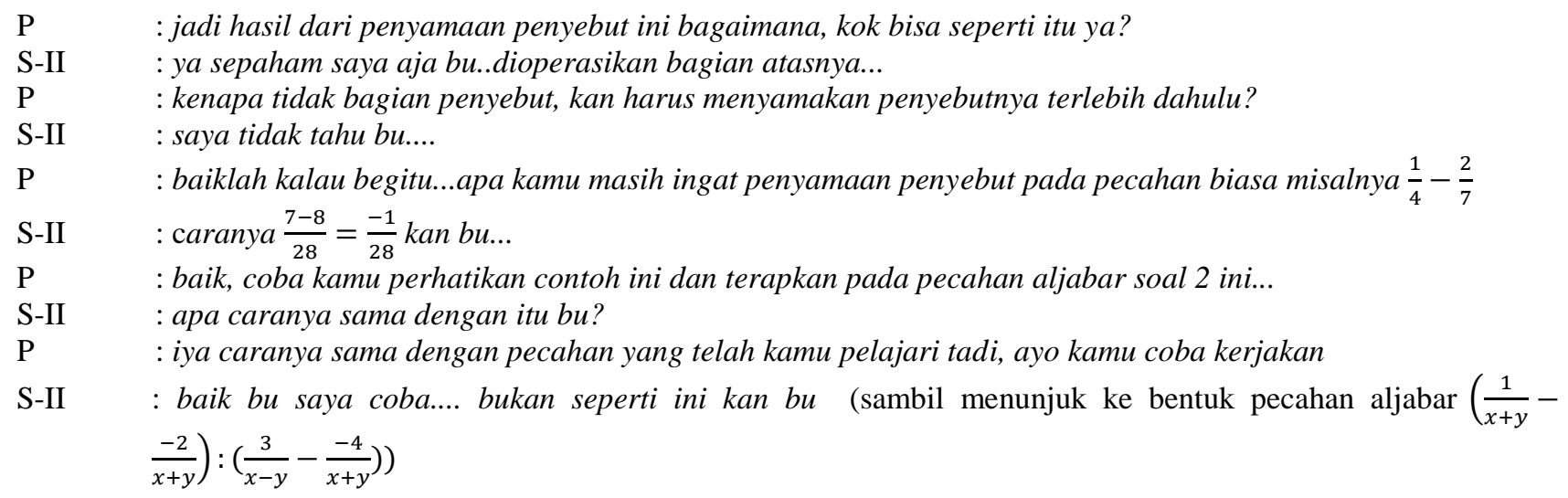

Dari hasil pekerjaan S-II pada penyamaan penyebut, kesalahan yang dilakukan S-II pada langkah ini disebabkan belum lancar dalam menggunakan konsep pecahan aljabar. Oleh karena itu scaffolding yang diberikan pada langkah penyamaan penyebut pada pecahan aljabar adalah dengan memberikan contoh pada penyamaan penyebut pecahan biasa kemudian memandu S-II mengerjakan pada konsep pecahan aljabar. Bentuk scaffolding yang diberikan adalah scaffolding reviewing dan developing conceptual thinking sebagai upaya meninjau kembali hasil pekerjaannya dan membangun kembali pemahamannya pada penyamaan penyebut.

\section{b. Perkalian Bentuk Aljabar}

Pada langkah ini, kesalahan dalam perkalian secara prosedural dan konsep ditandai dengan hasil pekerjaan S-II dalam menuliskan pembilang $2 x+2 y$ dan $2 x-2 y$. Jadi kedua pembilang yaitu $x+y$ dan $x-y$ tanpa disamakan penyebutnya masing-masing dikalikan dengan 2. Nilai 2 sendiri tidak diketahui diperoleh dari mana sehingga S-II menuliskan nilai 2 seperti tampak pada gambar 6.

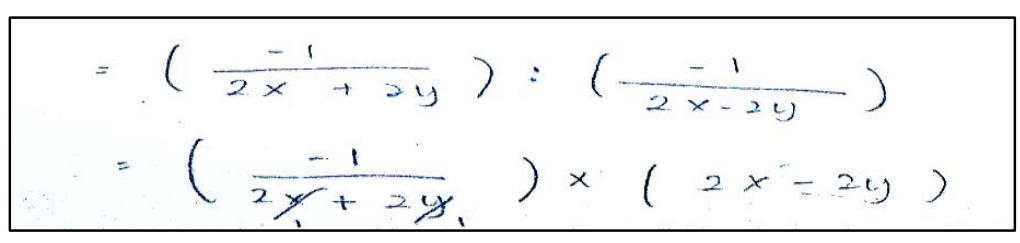

\section{Gambar 6. Hasil Pekerjaan S-II terhadap Perkalian}

Kesalahan perkalian juga berdasarkan hasil pekerjaan S-II adalah kesalahan dalam melakukan pencoretan $2 x+2 y$ Secara lebih rinci kesalahan-kesalahan yang dilakukan S-II dalam perkalian sebagai berikut.

1) Masing-masing penyebut $x+y$ dan $x-y$ dikalikan dengan 2

2) Pencoretan variabel $x$ dan $y$ dari $2 x+2 y$ yang menghasilkan 2

3) $(2 x-2 y)(2 x+2 y)=4 x^{2}+4 x y-2 x y-4 y^{2}$

Upaya tindak lanjut dalam mengatasi kesalahan dengan scaffolding yang diberikan kepada S-I adalah sebagai berikut.

$\mathrm{P} \quad$ : bagaimana kamu menyelesaikan perkalian ini? (sambil menunjuk ke pekerjaan S-II $(2 x-2 y)(2 x+2 y)$ )

S-II $\quad$ : salah bu....sebenarnya kemarin saya tidak tahu caranya makanya saya tulis seperti itu...

$\mathrm{P} \quad$ : harusnya bagaimana?

S-II : : ya seperti dikalikan gitu kan bu...

$\mathrm{P} \quad$ : yang mana yang kamu kalikan?

S-II : yang ini bu...

$\mathrm{P} \quad$ : oke sampai disini coba lihat pada bagian yang kamu coret ini maksudnya apa, kenapa dicoret?

S-II $\quad$ : karena pikir saya ya bu., -1 dikali $2 x-2 y$ dan dibagi $2 x+2 y \ldots$ kan $\frac{2 x}{2 x}=1$ dan $\frac{2 y}{2 y}=1$ juga bu...

$\mathrm{P} \quad$ : lho kok bisa? Apa sama bentuk $2 x-2 y$ dengan bentuk $2 x+2 y$ ? 
S-II : tidak bu....

$\mathrm{P} \quad$ : iya tidak sama jadi tidak bisa kita lakukan pencoretan seperti itu. Coba sekarang kembali pada langkah perkalian pembilang yang kamu kerjakan bagaimana?

S-II : seperti ini bu...

$$
=\left(\frac{x-y}{(x+y)(x-y)(x-y)(x+y)}\right):\left(\frac{3 x+3 y}{x-y(x+y)}+\frac{4 x-4 y}{x+y(x-y)}\right.
$$

Dari hasil wawancara dan pemberian scaffolding dapat diperoleh informasi bahwa kesalahan yang dilakukan oleh S-II pada perkalian ini baik secara prosedur maupun konsep belum baik. Dari hasil wawancara kepada subjek, kesalahan pada perkalian ini disebabkan karena kurangnya pemahaman subjek terhadap perkalian bentuk aljabar terutama pada pada perkalian aljabar ini. Oleh karena itu, scaffolding yang diberikan adalah scaffolding developing conceptual thinking kepada subjek karena kesalahan perkalian ini sangat diperlukan bagi subjek S-II.

\section{b. Pembagian Pecahan Bentuk Aljabar}

Kesalahan dalam pembagian aljabar berdasarkan hasil pekerjaan S-II pada soal tes adalah kesalahan prosedural dan konseptual yang ditandai dengan menuliskan $\frac{-1}{2 x+2 y}$ dan melakukan pencoretan pada variabel $x$ dan $y$ sebagai bagian dari langkah perkalian bentuk aljabar sebelumnya. Kemudian kesalahan dalam pembagian yang ditulis siswa $2 x-2 y$ sebagai hasil operasi dari balik dan kalikan $\frac{-1}{2 x-2 y}$ yang seharusnya adalah $-2 x+2 y$ seperti ditunjukan pada gambar 6 terhadap perkalian. Adapun scaffolding yang diberikan pada langkah ini dengan memberikan bantuan berupa reviewing dan restructuring seperti yang telah dijelaskan pada langkah perkalian diatas terhadap konsep pembagian dengan pencoretan.

\section{c. Penjumlahan dan Pengurangan Bentuk Aljabar}

Pada langkah ini, masih berhubungan dengan kesalahan dari langkah sebelumnya yakni penyamaan penyebut tampak kesalahan yang dilakukan siswa dalam operasi penjumlahan dan pengurangan. Operasi penjumlahan dan pengurangan yang dikerjakan S-II dengan menuliskan bahwa hasil operasi 1 dari $1-(-2)=3$ dan $3+(-4)=-1$. Selanjutnya S-II hanya berfokus pada operasi pembilang tanpa mengindahkan penyamaan penyebut. Peneliti memberikan scaffolding berupa reviewing pada penjumlahan dan pengurangan bentuk aljabar dengan maksud agar subjek dapat lebih memperhatikan langkah penjumlahan dan pengurangan bentuk aljabar.

S-II tidak menemukan bentuk paling sederhana pada soal tes dikarenakan langkah ini luput dari pengerjaan S-II. Hasil akhir yang dikerjakan oleh S-II bahwa bentuk sederhana adalah $\frac{-x+y}{2 x^{2}+x y-2 y}$. Adapun scaffolding yang diberikan kepada S-II pada langkah ini yaitu S-II diminta untuk mempelajari kembali penyelesaian soal pada pemfaktoran dan penyederhanaan. Kemudian S-II menyatakan sudah dapat menyelesaikan soal setelah mencoba memahami cara kerja pemfaktoran dan penyederhanaan, barulah peneliti memberikan tes evaluasi untuk dikerjakan oleh S-II.

\section{PEMBAHASAN}

\section{Deskripsi Kesalahan Subjek Dalam Menyederhanakan Pecahan Bentuk Aljabar}

Berdasarkan hasil pekerjaan subjek dalam menyederhanakan pecahan bentuk aljabar pada tes. Terdapat kesalahan prosedural maupun konseptual yang dilakukan subjek dalam mengerjakan soal yang diberikan. Kesalahan-kesalahan yang dilakukan subjek dikelompokan menjadi beberapa indikator kesalahan penting selama mengerjakan tes. Adapun kesalahankesalahan tersebut sebagai berikut.

Pertama, kesalahan dalam menyamakan penyebut. Kesalahan dalam menyamakan penyebut dilakukan oleh subjek S-I pada soal tes disebabkan karena kesalahan secara prosedur dan konseptual dalam menyamakan penyebut termasuk dalam menggunakan KPK dalam menyamakan penyebut tersebut dan kesalahan dari diri siswa yang tidak memahami maupun lupa tentang cara menyamakan penyebut sehingga kesalahan yang terjadi adalah kesalahan yang dikerjakan dalam menyamakan penyebut. Kesalahan yang dikerjakan pada soal ini disebabkan karena kesalahan dalam memahami penyamaan penyebut dengan bentuk kesalahan yang tidak sistematis operasi pada pembilang tanpa memperhatikan operasi pada penyebut dengan KPK.

Kedua, kesalahan pada pembagian aljabar. Dari hasil pekerjaan terdapat ketidakkonsistenan subjek dalam menuliskan operasi pada bentuk aljabar terutama pembagian. Setelah peneliti menanyakan kepada subjek dan diperoleh informasi bahwa kesalahan yang dilakukan oleh subjek disebabkan oleh tidak mengalikan pembilang dan penyebut dengan kebalikan/resiprokal dari penyebut dan ketidaktelitian dalam menuliskan pembagian bentuk aljabar tanpa didasari alasan yang jelas.

Sejalan dengan hasil penelitian ini menurut (DeWolf \& Vosniadou, 2011) siswa dalam membangun pengetahuan awal berdasarkan konsep sebelumnya. Pengetahuan awal inilah yang membentuk pengetahuan sebelumnya. Dari hasil pekerjaan siswa dan wawancara yang dilakukan kepada subjek yang mengalami kesalahan dalam pembagian aljabar ini, adanya indikasi kesalahan yang disebabkan konsep pada pecahan yang belum utuh sehingga menimbulkan miskonsepsi pada pecahan aljabar. Siswa melakukan perhitungan berdasarkan perhitungan aritmatika pada bilangan asli ke bilangan pecahan/rasional. Hal ini 
disebutkan oleh (Hidayanto, 2013) bahwa pengetahuan awal tersebut membentuk pemahaman bahkan untuk siswa menengah atas bahwa suatu perhitungan adalah bilangan sebagaimana adanya (aritmatika). Jadi, sifat-sifat yang ada pada bilangan bulat digenaralisasi pada bilangan pecahan padahal bilangan pecahan memiliki prosedur yang berbeda dengan operasi bilangan bulat. Misalnya siswa harus menggunakan sifat balik dan kalikan sebelum mengoperasikan pecahan ataupun dalam pembagian bentuk aljabar siswa harus memperhatikan faktor sekutu masing-masing sebelum membagi suatu bentuk aljabar (Ito, 2017).

Ketiga, kesalahan dalam perkalian aljabar. Kesalahan dalam perkalian aljabar dilakukan oleh S-I dan S-II pada soal tes. Kesalahan ini disebabkan tanda operasi pada perkalian bagian pembilang yang luput dari perhatian siswa terutama setelah menyamakan penyebut. Setelah ditanyakan kepada subjek tentang hasil pekerjaannya diperoleh informasi bahwa kesalahan yang dilakukannnya adalah karena ketidaktelitiannya dalam mengoperasikan perkalian bentuk aljabar soal tes tersebut. Yang terakhir kesalahan pada perkalian yang dilakukan oleh S-III pada soal tes ini disebabkan karena langkah yang salah dalam menyamakan penyebut kemudian berlanjut ke kesalahan dalam perkalian sehingga subjek menuliskan hasil perkalian yang melenceng dari hasil yang sebenarnya. Adanya kesalahan perkalian juga diutunjukan dengan cara pencoretan yang salah.

Keempat, kesalahan dalam penjumlahan aljabar. Kesalahan pada penjumlahan aljabar yang dilakukan masing-masing oleh S-I dan S-II pada soal tes disebabkan kesalahan karena ketidaktelitian dalam menggunakan langkah perkalian terutama tanda operasi pada perkalian bagian pembilang. Kemudian ketidakkonsistenan dalam menuliskan tanda operasi pada bentuk aljabar juga adalah penyebab kesalahan yang paling sering ditunjukan oleh subjek penelitian pada bagian ini. Hal ini dapat dikarenakan kesalahan subjek dalam memahami prosedur penjumlahan aljbar maupun kesalahan subjek karena langkah pada menyamakan penyebut yang jelas salah. S-I dalam penelitian ini juga ditemukan kesalahan dalam mengelompokkan suku-suku sejenis.

Kelima, kesalahan dalam pengurangan aljabar. Kesalahan yang dilakukan disebabkan kesalahan dalam penggunaan tanda operasi, kesalahan yang berasal dari hasil operasi penyamaan penyebut dan kesalahan memahami bentuk pengurangan aljabar yang dikerjakan oleh subjek, begitu pula S-II pada soal tes juga melakukan kesalahan yang serius pada pengurangan aljabar. Jika dilihat dari hasil pekerjaannya kesalahan yang dilakukan disebabkan karena kesalahan pada langkah sebelumnya yaitu kesalahan pada perkalian maupun penyamaan penyebut ditambah dalam melakukan pengurangan aljabar adanya bentuk pengurangan aljabar yang tidak sistematis dikarenakan ketidakcermatan siswa dalam berpikir aljabar.

Ketidaktelitian maupun kurang mahir yang dilakukan oleh siswa dapat diatasi dengan penguatan pada bagian pengurangan bentuk aljabar namun pada kasus lain kesalahan karena konseptual perlu upaya baik dalam operasi hitung bentuk aljabar maupun memahami konsep pengurangan dan penjumlahan pecahan bentuk aljabar. Hal yang sama dikemukan oleh Kieran (2004) bahwa salahsatu aktivitas dalam belajar aljabar adalah transformasi (the transformational, rule based) hal ini termasuk bagaimana siswa mengumpulkan suku-suku, subtitusi, menambahkan, menjumlahkan, mengalikan persamaan, menyederhanakan dan ain sebagainnya. Jika kesalahan terjadi pada transformasi berdasarkan aturan dasar ini maka disebut oleh Rushton (2014) sebagai kesalahan umum (common errors). Kesalahan yang sering terjadi pada operasi aljabar adalah menyusun ulang bentuk aljabar atau dalam hal ini operasi pada bentuk aljabar yang dilakukan oleh siswa.

Keenam, kesalahan dalam pemfaktoran. Pada kasus S-I pada soal tes juga kesalahan dalam pemfaktoran karena tidak mampu melihat faktor-faktor sekutu pada bentuk aljabar yang dimaksud. Dari hasil pekerjaan subjek S-I kesalahan yang dilakukan merupakan akumulasi kesalahan pada langkah-langkah sebelumnya yaitu menyamakan penyebut, perkalian, pembagian maupun penjumlahan dan pengurangan bentuk aljabar. Adanya kesalahan yang secara sistematis ini mengakibatkan hasil yang diperoleh juga salah. Sejalan dengan hasil temuan ini (Rushton, 2014) mengemukakan bahwa kesalahan yang dilakukan pada langkah pemfaktoran disebabkan oleh ketidakmampuan siswa dalam manipulasi aljabar atau menyusun persamaan, sedangkan (Kieran, 2004) mengemukakan pemfaktoran juga merupakan aktivitas berpikir aljabar yang berhubungan dengan mengubah ekspresi atau persamaan yang termasuk dalam tipe kedua dari aktivitas aljabar yaitu transformasi (berbasis aturan) setelah aktivitas generalisasi aljabar.

Ketujuh, Kesalahan dalam penenyederhanaan aljabar. Kesalahan dalam penyederhanaan dilakukan oleh semua subjek penelitian. Kesalahan ini disebabkan oleh kesalahan pada langkah pada pemfaktoran yang belum diselesaikan oleh subjek pada soal penyederhanaan pecahan bentuk aljabar maupun kesalahan dikarenakan tidak mampu memahami konsep penyederhanaan pecahan aljabar sehingga jika dipaparkan kesalahan dalam penyederhanaan.

\section{Deskripsi Scaffolding Kepada Subjek Dalam Menyederhanakan Pecahan Bentuk Aljabar}

(Misquitta, 2011) menawarkan pembelajaran pecahan dengan empat cara untuk meningkatkan kemampuan siswa dalam pecahan dan yang pertama kali ditawarkan adalah bagaimana guru menyajikan pembelajaran langsung, dengan strategi, dan pembelajaran secara bertahap. Dalam penelitian ini, strategi pembelajaran yang digunakan adalah proses scaffolding kepada subjek yang merupakan bagian penting dalam mengatasi masalah yaitu kesalahan siswa. Pembelajaran scaffolding direpresentasikan sebagai dukungan terhadap pembelajaran siswa sehingga dari proses scaffolding diharapkan ada peningkatan kemampuan siswa terhadap pecahan bentuk aljabar (Anghileri, 2006). Pada bagian ini, peneliti membahas bentuk scaffolding yang diberikan kepada subjek pada kesalahan langkah dalam menyelesaikan pecahan bentuk aljabar. Pemberian bantuan scaffolding yang diberikan peneliti kepada subjek berdasarkan kesalahan yang dilakukan oleh subjek adalah sebagai berikut. 
Pertama, Scaffolding terhadap kesalahan dalam menyamakan penyebut. Kesalahan dalam menyamakan penyebut yang dilakukan oleh subjek penelitian S-I. Adapun scaffolding yang diberikan adalah level 2 yaitu explaining, reviewing dan restructuring. Kurangnya ketelitian yang ditunjukan siswa selama pengerjaan soal menyebabkan soal yang dikerjakan dikaji lagi dan berulang agar dapat dimengerti dengan baik oleh siswa. Sedangkan developing conceptual thinking dimaksud untuk membangun kembali pemahaman konseptual terhadap menyamakan penyebut.

Kedua, Scaffolding terhadap kesalahan dalam melakukan pembagian aljabar. Untuk kesalahan pada pembagian aljabar ini, peneliti memberikan scaffolding kepada subjek S-I. Scaffolding kepada yang diberikan dengan developing conceptual thinking dengan maksud agar siswa dapat membangun kembali konsep pada pembagian aljabar dengan benar. Konsep yang dimiliki subjek pada pembagian yang masih salah dalam memahami pembagian aljabar. Subjek mengemukakan operasi pada perkalian sama dengan operasi pada pembagian sehingga tanpa memperhatikan tanda operasi pembagian langsung menuliskan hasil yang dipikirkannya.

Ketiga, Scaffolding terhadap kesalahan dalam perkalian aljabar. Scaffolding yang diberikan kepada subjek penelitian yaitu S-I dan S-II yang melakukan kesalahan dalam perkalian aljabar terutama disebabkan oleh tanda pada perkalian yang salah diberikan scaffolding reviewing terhadap hasil pekerjaan subjek. Hal ini dimaksudkan agar dapat membangkitkan perhatian siswa terhadap kesalahan dalam tanda operasi pada perkalian ini. Hal ini dikarenakan kesalahan sistematis berdampak pada pekerjaan siswa yang melenceng dari jawaban sebenarnya. Kesalahan yang lain adalah kesalahan karena tidak konsisten dari hasil pekerjaannya maka pada bagian ini diberikan scaffolding restructuring misalnya dalam sifat distributif perkalian.

Keempat, Scaffolding terhadap kesalahan dalam penjumlahan aljabar. Kesalahan yang dilakukan oleh subjek penelitian S-I dan S-II pada penjumlahan aljabar banyak dilakukan subjek karena tidak teliti dalam mengoperasikan penjumlahan aljabar dan kesalahan dalam mengelompokan suku-suku sejenis. Oleh karena itu, scaffolding yang diberikan dalam mengatasi kesalahan pada penjumlahan bentuk aljabar adalah reviewing kembali hasil pekerjaannya terhadap tanda operasi yang dikerjakan. Adapun jika kesalahan yang dilakukan subjek karena tidak mampu menggunakan tanda operasi aljabar maka diberikan scaffolding restructruring agar siswa dapat memahami operasi aljabar dan lancar dalam menggunakannya. Misalnya dalam operasi aljabar harus memperhatikan variabel yang sama.

Kelima, Scaffolding terhadap kesalahan dalam pengurangan aljabar. Scaffolding terhadap kesalahan pengurangan aljabar yang dilakukan oleh subjek penelitian S-I, S-II dan S-III. S-I kesalahannya pada ketidaktelitiaanya pada tanda operasi pengurangan diberikan scaffolding explaining. Hal ini karena S-I mampu menyadari kesalahannya dalam pengurangan aljabar dengan cepat. S-II mengalami kesalahan pada pengurang karena hasil pekerjaanya yang tidak konsisten adanya kesalahan ini memberikan ruang bagi reviewing kembali hasil pekerjaannya.

Keenam, Scaffolding terhadap kesalahan dalam pemfaktoran. Kesalahan dalam pemfaktoran dilakukan oleh subjek penelitian I. Untuk mengatasi kesalahan subjek dalam pemfaktoran ini yakni tidak melanjutkan hasil pekerjaanya dapat diberikan scaffolding reviewing. Hal ini dimaksudkan karena terkadang siswa tidak menyadari bentuk aljabar yang dapat diaktorkan dan kurang gigih mencari pemfaktoran tersebut. Scaffolding terhadap kesalahan dalam penyederhanaan pecahan aljabar.

Ketujuh, Scaffolding penyederhanaan aljabar. Kesalahan yang dilakukan oleh subjek S-I dan S-II adalah penyederhanaan pecahan bentuk aljabar. Kesalahan yang dilakukan adalah kesalahan baik secara prosedural maupun konseptual yang telah dibahas pada poin kesalahan diatas. Adapun scaffolding yang diberikan adalah scaffolding pada langkah pemfaktoran jika kesalahan awal dari pemfaktoran.

\section{SIMPULAN}

Siswa SMA Lab UM kelas XI IPS 1 tahun pelajaran 2018/2019 masih melakukan kesalahan dalam menyederhanakan pecahan bentuk aljabar. Kesalahan-kesalahan yang dilakukan siswa pada kasus yaitu (1) kesalahan dalam menyamakan penyebut; (2) kesalahan dalam melakukan pembagian aljabar; (3) kesalahan dalam perkalian aljabar; (4) kesalahan dalam penjumlahan aljabar; (5) kesalahan dalam pengurangan aljabar; (6) kesalahan dalam pemfaktoran aljabar; (7) kesalahan dalam penyederhanaan pecahan aljabar. Adapun kesalahan prosedural yaitu kesalahan karena kekurangtelitian, kesalahan ini berdampak pada hasil pekerjaan siswa sehingga tidak menemukan jawaban akhir yang tepat. Kesalahan menghitung juga memengaruhi hasil penyederhanaan seperti kesalahan tidak menggunakan aturan-aturan perkalian bentuk aljabar, kesalahan perkalian tanda negatif dengan negatif atau positif dengan negatif dan sebagainya. Adapun bentuk scaffolding yang diberikan kepada siswa kelas XI sesuai dengan kesalahan yang dilakukannya masing-masing, yaitu (1) kesalahan dalam menyamakan penyebut diberikan scaffolding reviewing dan developing conceptual thinking; (2) kesalahan dalam melakukan pembagian aljabar developing conceptual thinking; (3) kesalahan dalam perkalian aljabar yaitu scaffolding reviewing dan restructuring; (4) kesalahan dalam penjumlahan aljabar yaitu scaffolding reviewing dan restructuring; (5) kesalahan dalam pengurangan aljabar yaitu explaining dan reviewing; (6) kesalahan dalam pemfaktoran aljabar yaitu scaffolding reviewing; (7) kesalahan dalam penyederhanaan pecahan aljabar yaitu reviewing.

Peneliti ingin menyarankan peneliti menyarankan bahwa kajian penelitian ini masih terbatas penyederhanaan pecahan dengan indikator kesalahan penyamaan penyebut, pembagian aljabar, perkalian aljabar, pengurangan aljabar, pemfaktoran dan penyederhanaan pecahan aljabar. Untuk kedepannya peneliti lain dapat meneliti tentang pecahan aljabar misal pada limit fungsi. 


\section{DAFTAR RUJUKAN}

Anghileri, J. (2006). Scaffolding Practices that Enhance Mathematics Learning. Journal of Mathematics Teacher Education, 9(1), 33-52. https://doi.org/10.1007/s10857-006-9005-9

Bentley, B., \& Bossé, M. J. (2018). College Students' Understanding of Fraction Operations. International Electronic Journal of Mathematics Education, 13(3), 233-247. https://doi.org/10.12973/iejme/3881

Brodie, K. (2014). Learning about Learner Errors in Professional Learning Communities. Educational Studies in Mathematics, 85(2), 221-239. https://doi.org/10.1007/s10649-013-9507-1

Creswell, J. W. (2012). Research Design Pendekatan Kualitatif, Kuantitatif dan Mixed (Cetakan ke-2). Yogyakarta: Pustaka Pelajar.

Davis, E. A. (2015). Scaffolding Learning. Encyclopedia of Science Education, 21(2), 362-364. https://doi.org/10.1080/13664530.2016.1199398

DeWolf, M \& Vosniadou, S. (2011). The Whole Number in Fraction Magnitude Comparisons with Adults. Proceedings of the Annual Meeting of the Cognitive Science Society, 66-67. Athens, Greece: California Digital Library.

Egodawatte, G., \& Stoilescu, D. (2015). Grade 11 Students' Interconnected Use of Conceptual Knowledge, Procedural Skills, and Strategic Competence in Algebra: A Mixed Method Study of Error Analysis. European Journal of Science and Mathematics Education, 3(3), 289-305.

Hidayanto, E. (2013). Proses Berpikir Aritmetika dan Berpikir Aljabar Siswa Dalam Menyelesaikan Soal Cerita. Prosiding Seminar Nasional Aljabar dan Pembelajarannya, (April), 173-177. UM.

Ito, T. (2017). Effectiveness of Math in College Remedial Mathmatics Students. University Nevada.

Kieran, C. (2004). Algebraic Thinking in the Early Grades: What Is It? 1. The Mathematics Educator, 8(1), 139-151.

Maharani, I. P., \& Subanji, S. (2018). Scaffolding Based on Cognitive Conflict in Correcting the Students' Algebra Errors. International Electronic Journal of Mathematics Education, 13(2), 67-74. https://doi.org/10.12973/iejme/2697

Misquitta, R. (2011). A Review of the Literature: Fraction Instruction for Struggling Learners in Mathematics. Learning Disabilities Research \& Practice, 26(2), 109-119. https://doi.org/10.1111/j.1540-5826.2011.00330.x

Moleong, L. J. (2014). Metode Penelitian Kualitatif Edisi Revisi. Bandung: Remaja Rosdakarya.

Rushton. N. (2014). Common Errors in Mathematics. Research Matters: A. Research Matters. Cambridge Assesment Publication. Retrieved from http://www.cambridgeassessment.org.uk/research-matters

Ryan, J., \& McCrae, B. (2005). Subject Matter Knowledge: Mathematical Errors and Misconceptions of Beginning Pre-Service Teachers. Proceedings of the $29^{\text {th }}$ Annual Conference of the International Group for the Psychology of Mathematics Education, 641-648.

Sarwadi, H.R.H \& Shahrill, M. (2014). Understanding Students' Mathematical Errors and Misconceptions: The Case of Year 11 Repeating Students. Mathematics Education Trends and Research, 2014(September), 1-10. https://doi.org/10.5899/2014/metr-00051

Selden, A., \& Selden, J. (2009). Reflections on Foundations for Success: The Final Report of the National Mathematics Advisory Panel. The College Mathematics Journal, 40(4), 318.

Siegler, R. S., Thompson, C. A., \& Schneider, M. (2011). An Integrated Theory of Whole Number and Fractions Development. Cognitive Psychology, 62(4), 273-296. https://doi.org/10.1016/j.cogpsych.2011.03.001

Tariq, V. (2008). Defining the Problem: Mathematical Errors and Misconceptions Exhibited by First-Year Bioscience undergraduates. International Journal of Mathematical Education in Science and Technology, 39(7), 889-904. https://doi.org/DOI: 10.1080/00207390802136511

Walle, J. A. Van de. (2009). Matematika Sekolah Dasar dan Menengah (jilid 2). Jakarta: Erlangga. 